\title{
Female Monsters: Figuring Female Transgression in Jennifer's Body (2009) and The Witch (2013)
}

\author{
Aidatul Chusna; Shofi Mahmudah \\ Univeristas Jenderal Soedirman Purwokerto, Indonesia \\ Email: aidatul.chusna@gmail.com
}

\begin{abstract}
This paper aimed to examine the depiction of the monstrous feminine in two horror films, 2009's Jennifer 's Body and 2015's The Witch, by investigating how horror films confront transgression through the construction of woman as a monstrous figure in the story. The theory of abjection proposed by Julia Kristeva and of the monstrous feminine by Barbara Creed were used in the analysis. The main data were taken from these two films, focusing on the characterization and narrative aspects. It was found that the depiction of the monstrous feminine in both films was through the use of monstrous acts and images. The way in which these films constructed monstrosity indicates female transgression of patriarchal boundaries, specifically on the issue of gender identity and religiosity. The transgression emphasizes that there is no absolute identity, and thus boundaries are disrupted due to this fluid identity.
\end{abstract}

Keywords: abjection; boundaries; female monster; monstrous feminine; transgression

\section{INTRODUCTION}

Horror films have been produced since the first era of cinema. These stories are developed based on various types of sources, like ghost stories, myths, legends, and gothic Victorian literature. The horror genre has become one of the oldest and most popular genres in film history. The 2000s saw continued success for horror films, as exemplified by Scream 3 (2000), The Others (2001), The Ring (2002), The Grudge (2004), and Paranormal Activity (2009), which were the five highest-grossing horror films in the first decade of the $21^{\text {st }}$ century (Thompson, 2010). In the last few years, horror has been popularized by film franchises such as Paranormal Activity, Final Destination, I Spit on Your Grave, and Texas Chainsaw Massacre, as well as the creation of new monster characters like the doll in Annabelle (2014) and a nun ghost in The Conjuring (2013).

Along with contributing to the development of cinematography and the film industry itself, horror films have progressed in the stories they tell and the types of monster figures they depict. One of the popular types is the female monster. Many horror films present various characters in the form of female monsters, such as ghosts in The Shining (1980), The Others (2001), and Carved (2007); aliens in The Faculty (1998), Species (1995), and Under The Skin (2013); wolves in The Howling (1981) and Ginger Snaps (2001); witches in The Blair Witch Project (1999), The Witches (2013), and 7 Witches (2017); vampires in Daughters of Darkness (1973), The Hunger (1983), and Let the Right One In (2008); and evil demons in The Exorcist (1973), Night of the Demons (1988), and Jennifer's Body (2009).

The appeal of female monsters in horror films is interesting. Often, a female monster initially appears as a beautiful and seductive woman, but then she changes into a monstrous creature. This paper explores the depiction of woman-as-monster in two horror films, Jennifer's Body (2009) and The Witch (2015). These films were examined in how they confront female transgression through the construction of woman as a monstrous figure in their story. 
Horror films construct woman as the monstrous feminine. This portrayal raises concerns over its reversal of the stereotypes associated with women's natural roles in life. The horror emerges from the fact that the woman has broken with her proper feminine role - seen in her natural roles, such as that of a mother. Besides these natural roles, however, the depiction of woman as a monster in horror emphasizes the importance of gender in terms of monstrosity; a simple reversal of the traditional male monster but "as with all other stereotypes of the feminine is defined in terms of sexuality" (Creed, 1994: 3). Creed is focused on film's figuration of "woman as a monster" by adapting Kristeva’s abjection.

'Kristeva's theory of abjection provides us with an important theoretical framework for analysing, in the horror film, the representation of the monstrous feminine, in relation to woman's reproductive and mothering function. However, abjection by its very nature is ambigous; it both repels and attracts" (Creed 1994: 14).

Based on Kristeva and Creed's view of the monstrous feminine, the figure of woman as a monster becoming the abject is situated in a place which is not; excluded and threatening. The abject is put in the position of ambiguity (the abject itself both fascinates and horrifies) and transgression (crossing taboos and boundaries). The abject is considered in three aspects: bodily wastes, collapsing of boundaries, and maternal, and additionally religious discourses (Creed, 1994: 8). The subject can be the abject if it signifies a border between two entities or territories (Creed, 1994: 9). However, societies situate humans separated from the non-human; the good from the evil; the religie, which disturbs this identity, system, and order. The presence of the monstrous feminine in the horror film nonetheless challenges to expel the normal boundaries in society.

This research was based on qualitative data since it adopts a philosophical approach, specifically postfeminism, in film's figuration. The study was conducted in order to collect and describe information about the monstrous feminine in horror and horror films. Thus, understanding and exploring the data, along with the theoretical approach, will help to provide answers to the research question. This qualitative research included descriptive material, such as articles related to the topic, documents, and notes on the selected films (The Witch and Jennifer's
Body). The methods also included data analysis based on the theoretical approach employed in this research.

The data were collected from the selected films by studying their characters and those who depict the monstrous feminine, which is the central issue in this research, while related articles supporting the research analysis were collected as secondary data. Data analysis is the deployment of a series of methods or techniques in order to draw a relation between data, which is then boiled down to scientific knowledge (Faruk, 2012: 24). As such, the selected data were grouped and analyzed by relating the monstrous characters in the films based on the theoretical concepts - abjection (and its transgression). This drew the depiction of the monstrous feminine as the abject, which was then analyzed in how the abject would transgress taboos and boundaries. This process of analyzing should answer the research question based on Creed and Kristeva's view on the monstrous feminine and abjection.

\section{FINDINGS AND DISCUSSION}

Film has become a medium that offers different types of stories while bringing up the same issue (Rudy, 2016: 60). In this study, films were the media through which the issue of the female monster would be explored. One of the genres to depict female monsters is horror, which is a popular product - as a pop culture product, it expresses complex feelings, values, and ideas through symbols and myths (Cawelty, 1976: 27). The flourishing of horror films has continued even in the modern era, with its increasingly diverse genres. Jennifer's Body (2009) and The Witch (2013) present issues of abjection through images and the acts of their characters. Bloody scenes in the films arouse horror and disgust in viewers. Abjection leads to the construction of the monstrosity of the main characters in the films. Jennifer and Thomasin, the monstrous feminine figures depicted in Jennifer's Body and The Witch, respectively, attempt to cross over the boundaries that suppress them. The construction of female monstrosity itself also challenges the common reading of female characters in horror films, which are always pictured as victims.

\section{Jennifer's Body (2009): Transgressing Identity}

Alternative View towards Gender Identity

Jennifer's Body opens by showing the close and supportive friendship between two schoolmates, 
Needy and Jennifer. They seem like the polar opposites of each other-Jennifer is a sexy cheerleader who always dresses provocatively, while Needy is a nerdy tomboy. In spite of their different personalities, they remain close and maintain a very good relationship, as a "best friend" does. Their good relationship is also symbolized in Jennifer's necklace. However, everything changes when the friends meet Jennifer's favorite band, Low Shoulder, at a local bar called Melody Lane. A fire burns down the bar, leading the lead singer of Low Shoulder to invite Jennifer into the band's van. The band then takes her to a whirlpool to be sacrificed to Satan in return for chart success. In the climax of their occult ritual, the lead singer stabs Jennifer and throws the knife into the whirlpool. Soon after, Jennifer begins to act oddly, which Needy can't help but notice.

In this film, Jennifer is characterized as a girl who is alluring but confronting. She portrays her sexuality in the manner of a young, beautiful, and attractive girl, but she uses her appeal to prey on the boys in her school. Her confrontation is not directly addressed to her victims; she otherwise abuses her sexuality to prey on them. The character displayed on the screen is played by a young, beautiful, and sexually attractive actress, Megan Fox, whose allure suits the role. Therefore, the idea that a "woman's evil nature lies inside the body of a beautiful woman" (Creed, 1994: 8) works in a patriarchal society, which will be further discussed in this paper.

Creed challenges this patriarchal view that woman, with her beauty and evil nature, makes her castrated. Creed offers an alternative view of the monstrous-feminine as the one who is castrating instead of being castrated; and "the presence of monstrous feminine does challenge the view that the male spectator is almost always situated in active, sadistic position and female spectator as in a passive, masochistic one" (Creed, 1994: 7). Here, Jennifer's Body presents the castrating monstrous feminine. In another words, the monstrous feminine portrayed by Jennifer has the possibility to castrate - castrating or active or threatening to one's identity.

After Jennifer is sacrificed at the whirlpool, she ruthlessly pursues a number of boys at her school by exploiting their desire to date her. The figuration of Jennifer as the one preying on boys as her victims suggests an instability of gender identity. Jennifer's character either challenges or confronts the patriarchal view towards gender identity - on how males become predators through the helplessness of their victims.
Within patriarchal society, the view towards gender identity is that the one who is violent, ruthless, and powerful is the man. The film's depiction of Jennifer's actions disrupts this idealization of gender roles. A woman can be violent, ruthless, and powerful, and this is threatening. Creed asserts in her theory that the patriarchal view is mythical (Creed, 1994: 1-3), which means that the patriarchal view is not an absolute view towards gender identity. One may cross this border between male and female, or somehow in between or beyond these categories. Based on this action performed by Jennifer, the stability of gender identity has been disrupted; and the patriarchal view towards gender roles has been falsified.

To some extent, this paper will not argue more on how this film offers an alternative view towards gender identity, but rather to explicate how it also performs horror because the films portray figures that spectators are followed to feel as Kasiyarno states that "... movies are produced to offer a chance for people to feel and taste and thus to satisfy them" (Rudy, 2016: 61). The films produce both shock and pleasure of perversity through the depiction of the monstrous feminine; and how this horror potentially works for viewing transgression of identity. Based on Creed's view on horror films as a work of abjection, I will then closely examine how the monstrous feminine is portrayed in relation to the construction of abjection. The notion of boundaries is evident to communicate transgression by which the monstrous act occurs. The image of abjection is then scrutinized by the notion of the corpse, bodily waste, and its border.

\section{Construction of Abjection}

Creed proposes that abjection occurs where the individual fails to respect a border. Jennifer's Body can be seen as a response to Creed's view on the monstrous feminine and how it presents the construction of abjection through the portrayal of the monstrous feminine, which disrupts, collapses, or threatens the border.

The place of the abject is the place where meaning collapses, the place where I am not. The abject threatens life; it must be eradically excluded from the place of the living subject, propelled away from the body and deposited on the other side of an imaginary border which separates the self from that which threatens the self (Creed, 1994: 9). 
Therefore, the construction of abjection performed by the monstrous feminine can be closely examined in such notions: the feminine bodycontaining bodily wastes and borders (Creed, 1994, p. 8). The film positions Jennifer in a visibly monstrous style of femininity-zombielike (which becomes the figure of abjection). Jennifer begins to perform her monstrous acts after having dates with boys. She behaves like a predatory zombie, ripping the bodies of her male victims, shredding them, biting them, and clawing parts of their bodies until they are thoroughly destroyed. She then consumes these male victims as her source of nourishment. In these scenes, Jennifer's aberrant behavior also reveals her defilement of her body (mouth and hands covered in blood), which suggests perversity. She seems to enjoy and drown herself in this pleasurable monstrous act. Through the film, this monstrous act evokes both shocking/ horrific images and the pleasure of perversity. At the same time, it also constructs these terrifying images as the abject.

To explain further, first, the abject is constructed by the image of the feminine body, which emphasizes an innermost marker as a sexual being. Therefore, this does not deny its natural role in relation to mothering and reproductive functions, which is by nature, an abject being. Consequently, these functions lead to the categorization of "excremental and menstrual", related to the production of such bodily wastes as blood, vomit, saliva, and other kinds of disgusting substances excreted from the body. In real life, all of these wastes are apart from a woman's body; they are identified as something that does not belong to a woman or even human. In fact, the body is not always pure and clean. It is a part of ourselves but we identify it as something we are not. To consider beauty, within patriarchal society, is by attaching to it a clean and proper body, which means rejecting the aforementioned natural bodily functions. At this stage, somehow, the waste becomes the abject when it is ejected-it is rejected. This in visible through the notion of the blood all over Jennifer's body down to her legs, in a scene in which she is found in Needy's kitchen looking for something to eat, and then after she vomits that food out along with a large amount of black ooze or liquid. The blood on her body symbolizes menstrual blood, while the blackened vomit in turn symbolizes an excremental substance. Femininity is, through these images of horror, highlighted by the true nature of its biological bodily functions.

Jennifer's character disrupts the human subject's apparent stability (Creed, 1994: 38); that is defined by sexuality, which is represented by the bodily products ejected by Jennifer: spurting black ooze and streaming blood. Through this depiction of vomit and blood, viewers look back to a time when bodily waste was not regarded with shame or embarrassment. Otherwise, this abject evokes shock in order to fascinate the audience, which has long been one of the central appeals of the horror genre. It could be underlined that the notion of the abject based on the mentioned portrayals (excremental and menstrual substances) signifies borders between the human and inhuman, purity and impurity, and good and evil.

The content and volume of Jennifer's vomit (the black ooze) is unusual for a human, even though humans can, under specific conditions, vomit as well. The black ooze, which is more reminiscent of blood clots-menstrual blood-represents "pollution". Menstrual blood is a polluting substance associated with the inherent impurity of the biological process, both as a human and a woman. The impurity comes within the concept of bodily secretion - as a waste-which should be thrown away from the body. However, through this menstrual blood, woman asserts her power as well as danger or threat. Just as this bodily substance is polluting, woman is potentially threatening to others - in relation to "castrating woman". This menstrual blood symbolizes that woman gains her power to threaten males by this fear of being poisoned or an inclination of being contaminated with pollution. The body, with its polluting substance, does not merely denigrate the position of a woman in social discourse; it also elevates her in how she could assert her power and threaten another's identity. The image of monstrous femininity, which emphasizes the feminine body, suggests woman is an impure or polluted subject. However, at the same time, being a threatening subject positions a woman as inhuman, and somehow can shift those two categories between a pure/clean being and a real human. The fluidity of woman - her gender identity - is unstable. Therefore, based on the portrayal of the monstrous feminine, a woman becomes the abject that signifies two different entities (Creed, 1994: 9)-here is the identity - between purity and impurity, and human and inhuman, as well.

Second, the construction of abjection is also seen in the "corpse"-we identify this term as the fluidity of the body: a body which has a soul and one which does not. In the film, the portrayal of the "corpse" is shown in Jennifer's ripping of corpses and eating 
flesh. For example, in one scene, Jennifer persuades a character named Jason to go to the woods, and they subsequently are seen kissing before she murders him. It is revealed that Jennifer had eviscerated his body to be eaten. Jennifer also seduces another schoolmate, Colin, who then agrees to meet Jennifer at her house. Once in her house, he is attacked and devoured. The next victim is Needy's boyfriend, Chip, from whose neck Jennifer drinks vampirically. These actions performed by Jennifer are violent and ruthless, yet she seems to revel in their cruelty. The images portrayed suggest that the "corpse", or the concept of that which protects its soul and the body in which there resides no soul can shift into a threat for others-related to the position of being between human and inhuman, as well as good and evil — that inside the body of Jennifer resides no soul. This zombielike body destroys other people and rips and consumes their flesh. This fluidity of identity hints at the body of a woman as the abject which disrupts the border.

In summary, collapsing (transgressing) boundaries are when the woman can cross or even go beyond the border between purity and impurity, good and evil, and human and inhuman. The subject as the abject is that woman as a monster can transgress the border which separates the living subject from that which threatens its extinction (Creed, 1994: 10).

\section{The Witch (2013): Transgressing Puritan Boundaries}

The Witch (2013) tells of a young girl named Thomasin who is accused of being a witch by her own family. Thomasin's family lives a secluded life near a forest, after the expulsion of the colony who accused them of speaking ill to God. Ever since, the family has experienced a series of mysterious events, which lead to the death of Thomasin's brothers. The first incident to occur is the disappearance of her infant brother who is under her care. Thomasin and another brother go looking for the infant in the forest, when he, too, also goes missing. The disappearance of the two male members of the family is attributed to the deeds of a witch who lives in the forest. The film ends with a gruesome scene in which Thomasin's family is murdered and she leaves their dead bodies behind to join a group of witches in the deep forest.

\section{The Monstrous Feminine as the Abject}

As the film's title suggests, the figure of the witch becomes what Barbara Creed called the monstrous feminine. In this horror film, the witch is depicted in two ways: as a sexually attractive woman and as a terrifying figure. The mise-en-scène of the film shows how Caleb, Thomasin's teenage brother, is "bewitched" by the alluring beauty of a mysterious woman in the deep forest. The woman, who is a witch, is described as a beautiful woman with long, dark, curly hair, and is dressed in a red coat, walking towards Caleb and kissing him. The teenage boy surrenders to her enchantment. It is in stark contrast to the horrifying scene that reveals the full impact of the witch's spell on Caleb. He is found naked and weak on a rainy night, and dies shortly thereafter whilst reciting a prayer continuously asking for God's forgiveness. Caleb's encounter with a witch reflects the image of woman as "deceptively treacherous" (Creed, 1994: 166), which is believed by patriarchal society.

The terrifying figure of the witch is described not only through her figure but also through her actions. In the beginning of the film, the monstrosity of the witch is shown in the slaughter of a baby, whose blood is then smeared on her body. Another bloody scene depicts a raven pecking the mother's breast as she hallucinates about breastfeeding her lost infant. Amongst the violence shown in the film's ending is the murder of the girl's father by Black Phillip - the embodiment of Satan - and Thomasin's own murder of her mother.

The concept of abjection also appears in religious discourse. Religious archetypes of woman as sinner, such as the story of Adam and Eve, have contributed to the continuous assumption of the inherent evil of women. Even with the passage of time and introduction of new interpretations of the story of Adam and Eve, one belief remains stable, as Pagels mentions that "Eve disobeyed God's admonition in the Garden to not eat the fruit of the one designated tree; the snake (Satan) tempted her into taking a bite of the now totally symbolic apple. Eve, in turn, tempted Adam to eat of the apple as well..." (Lawless, 2003: 242). Pagels further concludes that despite the various versions of the story, the one to always be hated and blamed is Eve. She has come to epitomize the "lustful, untrustworthy, wily, beguiling, deceitful, seducing, and evil in the universe". The attributes represent woman as an abject, which should be detachable. Woman as a witch in Puritan society, as the film exposits, represents the above description. Thomasin's family's fear that she has joined a coven of witches is meant as a punishment from God; thus, Thomasin must confess and pray for God's forgiveness. 


\section{The Transgression in The Witch}

According to Creed, the monstrous feminine becomes the abject as she "crosses or threatens to cross the border". The construction of the monster as an abject, as Creed further argues, functions as an encounter between the symbolic order and that which threatens its stability. The figure of the witch is associated with the border between the normal and supernatural, between good and evil. The two main settings of the film, the house and the forest, also have symbolic meaning, as representations of the "two worlds" between the normal (the family/society) and the supernatural (the witch). A river separating the two settings functions as a liminal space to represent the boundary between the house (the present, in which Thomasin belongs to her family and patriarchal society) and the forest (to which she will ultimately withdraw to join a coven). This boundary does not make her a secluded being or an absolute being with a fixed identity; through this boundary, Thomasin's identity becomes fluid.

Historically, in the fourteenth century, witchcraft was condemned as heresy by the Catholic Church. A witch would be burnt for her sin of collaborating with the Devil. Puritans condemned witchcraft for its satanic associations. For Puritans, witchcraft and women were closely linked. They believed that women were more vulnerable to the Devil's molestation (Reis, 1997: 5), due to the feminine attributes inherent in women. The male-dominated Puritan society believed that women's bodies and souls were weak, submissive, and passive; thus, it was easier for the Devil to attack and penetrate them. The story of Adam and Eve affected Puritans' belief that Eve's credulity and deceit had led to Adam's - and thus humanity's - downfall. Thus, she was justifiably condemned to suffer childbirth, work hard, and to be a faithful and submissive wife. This became the foundation of patriarchal practices in Puritan society (Florence, 2016).

This belief is represented by Thomasin's family. Family symbolizes the Puritan church, as stated by William Gouge that "a family is a little church, and a little Commonwealth... whereby tryall may be made of such as are fit for any place of authority, or of subjection in Church or Common-wealth. Or it is a schoole wherein the first principle and grounds of government and subjection are learned: whereby men are fitted to greater matters in Church or Commonwealth," (Porterfield, 1992: 24). Women's submission is seen through the mother's devotion to domestic roles as a wife and mother. Koehler in A Search for
Power mentions that "Puritan divines affirmed the 'natural' superiority of husband over wife and urged wives not to become too familiar with their mates. From parent, husband, and pulpit, Puritan women learned that they were supposed to submit to male rule." Motherhood was another crucial matter for Puritan women, as Ulrich said that in marital life, women had the greatest responsibility and burden in the task of reproduction that God has imposed on human beings (Muhni, 2010: 159).

However, the increasing conflict between Thomasin and her mother indicates the opposing figure of woman. Thomasin's mother represents the figure of a Puritan woman who is always a devotee to Puritan beliefs, whereas Thomasin is considered an enemy for making a deal with the Devil. Thomasin's choice to sign a pact with the Devil is evidence of her transgression of the Puritan religious beliefs that repressed her. Thomasin's transgression is seen through her sexualized body.

In Puritan beliefs, sexuality is acceptable only as a means of reproduction. Therefore, it is associated with marital affection, but not a loving relationship, which presupposed adultery (Porterfield, 1992: 21). Thomasin's maturing body has become the locus of the abjection that threatens Puritanism. It is reflected in the mother's fear of Thomasin's sexual body, which may attract the male members of the family, the father and the brother. Caleb's obsession with Thomasin's breast signifies female transgression that seduces and destroys male power. The story of Adam and Eve and the forbidden fruit is also projected in the scene of Caleb wandering the forest looking for an apple - that is, the missing infant - and coming back naked after the witch had seduced him. He coughs up an apple in the middle of his prayer for salvation and dies. This scene implies the abjection of the witch as a monstrous feminine creating male fear of castrating woman.

The deadly beauty of the witch described in the film exemplifies the monstrous feminine as a femme catastrice. In The Malleus Maleficarum, an inquisitor's manual for witch prosecution commissioned by Catholic Church, the main reason for prosecution is the fear of witch/woman as an agent of castration. "Witch's alleged crimes were of sexual nature... among other things, of copulating with the devil, causing male impotence, causing penis to disappear and of stealing men's penises - the latter crimes no doubt exemplify male fears of castration," (Creed, 1994: 75).

In horror films, the monstrous feminine is presented in woman as castrated and woman as 
castrator (Creed, 1994: 25). In this film, Thomasin's choice to become a witch is her way of releasing her disappointment towards her family's misjudgment of her making a pact with the Devil and of being the cause of their misery. Thomasin's transformation is the manifestation of her anger as, symbolically, she is castrated by the family. Also, Thomasin's choice reflects her transgression of Puritanism's boundaries, which castrate her as a young woman.

\section{CONCLUSION}

Jennifer's Body (2009) and The Witch (2013) are two films that portray woman as monster. The first film depicts a female character named Jennifer, a highschooler who becomes a zombie (flesh-eating woman), while the second focuses on Thomasin, a teenage Puritan girl, who is accused of witchcraft. Based on the analysis above, we can see that even though each film features a different type of monster, both characters play the role of the monstrous feminine as the abject who transgresses patriarchal boundaries. The depiction of the monstrous feminine is seen through the acts and images of monstrosity in both films. The monstrous acts performed by Jennifer include expelling bodily waste and violently murdering her male schoolmates and eating their flesh. Meanwhile, in The Witch, an infant is slaughtered and has its blood smeared on the female killer's body. All of these acts emphasized the images of monstrosity in the films, particularly the blood, vomit, and other disgusting substances produced by the body. Through these two elements - acts and images of monstrosity - Creed's view towards film's figuration of the monstrous feminine applies in a discussion of the issues encountered in both of these horror films. In addition, by applying Creed's theory, it can be concluded that the monstrous feminine suggests the transgression of patriarchal boundaries, specifically over the issue of gender identity and religious discourse. The monsters in both horror films use their sexual body to threaten the stability of identity and religiosity; the monsters also exhibit fluidity between these borders - be they in the boundary or beyond.

\section{REFERENCES}

Cawelty, J. G. (1976). Adventure, mystery, and romance: Formula stories as art and popular culture. Chicago and London: University of Chicago Press.

Creed, B. (1994). The Monstrous-Feminine film, feminism, psychoanalysis. (T. Bennet \& G. Martin, Eds.). London: Routledge.

Faruk. (2012). Metode Penelitian Sastra: Sebuah Penjelajahan Awal. Yogyakarta: Pustaka Pelajar.

Florence, D. et al. (2016). Engendering Psychology: Women and Gender Revisited. London: Routledge.

Lawless, E. (2003). Women as Abject: Resisting Cultural and Religious Myths that Condone Violence against Women. Western Folklore, 62 (4), pp. 237-269.

Muhni, D. (2010). Bunga Rampai dari Amerika. Yogyakarta: Impulse.

Porterfield, A. (1992). Female Piety in Puritan New England. Oxford: OUP.

Reis, E. (1997). Damned Women: Sinners and Witches in Puritan New England. Ithaca and London: Cornell University Press.

Rudy, R. (2016). The Depiction of Homosexuality in American Movies. Humaniora, 28 (1), pp. 59-68. https://doi.org/https://doi.org/10.22146/ jh.v28i1.11502

Thompson, M. (2010). Ranked: The Best Horror Films Since 2000. Retrieved from http://metacritic.com 